\title{
PENGARUH TERAPI KELUARGA TERHADAP DUKUNGAN KELUARGA DALAM MERAWAT KLIEN DENGAN MASALAH DIABETES MILLITUS
}

\section{(EFFECT OF FAMILY THERAPY ON FAMILY SUPPORT IN CARING FOR CLIENTS WITH DIABETES MILLITUS)}

\author{
Yudha Jatmika ${ }^{1}$, Puspa Fitriyana ${ }^{2}$, Jamilatul Komari ${ }^{3}$, Chairun $\mathrm{Nisak}^{4}$, Novaria \\ Puspitasari $^{5}$, Novita Nurkamilah ${ }^{6}$, Siti Aisyah Asri ${ }^{7}$, Mayangga Sukma ${ }^{8}$, Hanny \\ Rasni $^{9}$ \\ 1,2,3,4,5,6,7,8,9 Fakultas Keperawatan Universitas Jember \\ Jl. Kalimantan No. 37 Kampus Tegal Boto Jember Telp./Fax. (0331) 323450 \\ *e-mail: jamilatul.komari@gmail.com
}

\begin{abstract}
ABSTRAK
Dukungan keluarga adalah bentuk bantuan yang diberikan salah satu anggota keluarga untuk memberi kenyamanan fisik dan psikologis pada saat seseorang mengalami sakit. Penelitian ini bertujuan menganalisa pengaruh Pengaruh Terapi Keluarga terhadap Dukungan Keluarga dalam Merawat Klien dengan Masalah Diabetes Millitus. Penelitian ini menggunakan metode intervensi semu (quasi experiment) dengan rancangan pre-post test with control group design untuk mengetahui pengaruh terapi keluarga terhadap dukungan keluarga dalam merawat klien dengan masalah perilaku kekerasan. Responden penelitian dibagi dalam dua kelompok yaitu kelompok intervensi (perlakuan) dan kelompok kontrol (tanpa perlakukan) kemudian intervensi terapi keluarga diberikan pada kelompok intervensi, sedangkan kelompok kontrol tidak mendapatkan intervensi terapi keluarga. Subyek penelitian ini adalah 2 keluarga yang memenuhi kriteria inklusi. . Teknik sampel yang digunakan adalah consecutive sampling yang terdiri dari 2 keluarga. Data dianalisis dengan menggunakan uji t dependen dengan taraf signifikansi 0,05. Hasil uji $\mathrm{t}$ dependen menunjukkan perbedaan signifikan. Terapi edukasi keluarga dapat meningkatkan dukungan keluarga dalam merawat anggota keluarganya yang menderita DM tipe 2 di desa Serut $(\mathrm{p}=0,001)$.

Kata kunci: Terapi keluarga, Dukungan Keluarga, Diabetes Mellitus
\end{abstract}

\section{ABSTRACT}

Family support is a form of help given by one family member to provide physical and psychological comfort when someone is sick. This study aims to analyze the influence of Family Therapy Effects on Family Support in Caring for Clients with Diabetes Millitus Problems. This research uses quasi experiment method with pre-post test design with control group design to know the influence of family therapy on family support in caring for client with violent behavior problem. The study respondents were divided into two groups: the intervention group (treatment) and the control group (without treatment), then the family therapy intervention was given to the intervention group, while the control group did not get family therapy intervention. The subjects of this study were 2 families who met the inclusion criteria. The sample technique used is consecutive sampling consisting of 2 families. Data were analyzed by using t test dependent with level of significance 0,05. The result of t test dependent showed significant difference. Family education therapy can increase family support in caring for family members who have type 2 
diabetes in Serut village $(p=0.001)$.

Keywords: Family Therapy, Family support, Diabetes Millitus

\section{PENDAHULUAN}

Diabetes mellitus (DM) merupakan sekumpulan gangguan metabolik yang ditandai dengan peningkatan kadar glukosa dalam darah (hiperglikemia) akibat kerusakan pada sekresi insulin, kerja insulin, atau keduanya. Hiperglikemia jangka panjang dapat berperan menyebabkan komplikasi mikrovaskular dan makrovaskular (Smeltzer, 2013, p.211). Berdasarkan hasil riset data International Diabetes Federation (IDF), sepuluh negara diperkirakan memiliki angka tertinggi penderita DM pada tahun 2013 salah satunya Indonesia muncul dalam daftar ketujuh dengan prevalensi 8,5\% (IDF, 2013, p.13). Sementara itu, di Aceh memiliki peringkat tertinggi kesembilan dengan prevalensi berdasarkan diagnosis atau gejala sebesar 2,6\%, sedangkan prevalensi DM yang pernah didiagnosis sebesar 1,8\% (Depkes, 2013, p.89).

Dukungan keluarga adalah bentuk bantuan yang diberikan salah satu anggota keluarga untuk memberi kenyamanan fisik dan psikologis pada saat seseorang mengalami sakit (Friedman, 2014). Keluarga mempunyai peran yang sangat penting bagi kelangsungan hidup penderita diabetes melitus. Menurut penelitian yang dilakukan Skarbec (2006), ditemukan bahwa peran keluarga mempunyai hubungan yang kuat terhadap status kesehatan penderita DM, dimana kurangnya dukungan keluarga akan mempengaruhi kontrol gula darah dan menajemen DM sehingga kualitas hidup akan menurun. Dapat disimpulkan bahwa dukungan keluarga sangat penting dan berpengaruh terhadap kualitas hidup penderita DM.

Menurut Hensarling dalam Yusra (2011 ), ada 4 dimensi yang terkandung di dalam dukungan keluarga meliputi dukungan emosional, dukungan penghargaan, dukungan instrumental dan dukungan informatif. Penderita DM mempunyai dukungan keluarga yang baik maka penderita akan melakukan sikap positif yaitu dengan melakukan aktivitasaktivitas yang bermanfaat dan akan meningkatkan kualitas hidupnya, sebaliknya penderita DM yang minim atau tidak mempunyai dukungan keluarga maka cenderung melakukan sikap negatif yaitu melakukan kegiatan yang merugikan diri sendiri dan akan menurunkan kualitas hidupnya (Soegondo, 2006).

Semua anggota keluarga saling mempengaruhi satu dan lainnya melalui interaksi dan saling memberikan support dalam memperlihatkan fungsi dasar yang perlu untuk kesejahteraan keluarga. Jika keluarga memiliki pengaruh yang positif pada anggotanya, mereka akan mempunyai rasa dan pengakuan diri serta harga diri yang positif, dan akan menjadi produktif sebagai anggota masyarakat.

Berdasarkan hasil penjajakan di tiga Dusun Desa Serut Kecamatan Panti Kabupaten Jember didapatkan 4 keluarga yang memiliki anggota keluarga yang mengalami DM. Berdasarkan wawancara dengan anggota keluarga yang mengalami DM menyatakan bahwa dukungan keluarga sangat mereka butuhkan selama mendapatkan perawatan DM.

Klien dan keluarga merupakan komponen yang bekerja sama dalam suatu treatment. Oleh karena itu bertambahnya pengetahuan informal caregiver dan klien, maka semakin besar peluang tercapainya kesehatan dan hal-hal yang mendukung terwujudnya kesehatan. Berdasarkan uraian di atas, penulis bermaksud melakukan 
penelitian tentang pengaruh terapi keluarga terhadap Dukungan Keluarga dalam Merawat Klien dengan Masalah Diabetes Millitus di Dusun Krajan Desa Serut Kecamatan Panti Kabupaten Jember.

Diabetes melitus (DM) merupakan suatu keadaan dimana tubuh tidak mampu menggunakan insulin yang dihasilkan oleh pankreas (Word Health Organization [WHO], 2011). DM termasuk dalam golongan penyakit kronik yang terjadi pada jutaan orang di dunia (American Diabetes Asosiation [ADA], 2015). Di dunia penderita DM pada tahun 2002 mencapai 171 juta orang dan akan terus meningkat hingga 366 juta orang di tahun 2030 (WHO, 2006). Di Indonesia penderita DM sangat banyak. Pada tahun 2013, Indonesia menduduki peringkat ke tujuh di tingkat dunia dengan jumlah penderita DM sebanyak 7,6 juta jiwa dan jumlah itu diperkirakan akan terus meningkat di setiap tahunnya sebanyak 6 persen (Rachmaningtyas, 2013).

Terapi keluarga (family therapy) adalah suatu teknik yang digunakan untuk sebuah pendekatan psikoterapi yang membantu anggota keluarga mencapai pengertian yang mendalam dalam mengatasi permasalahan mereka dan merubah perilaku serta emosi dari yang disfungsi ke arah yang lebih sehat. Dengan menggunakan metode ini, keluarga dapat memperlihatkan perlunya dasar dari fungsi untuk menyehatkan seluruh anggota keluarga. Sehingga terapi ini diperuntukkan bagi keluarga yang tidak mampu memperlihatkan fungsi dasar ini secara adekuat (Shives, 1998). Didalam laporan kejadian pelaksanaan terapi keluarga yang dilaporkan oleh Straton dari Leed Family Therapy dan Research Centre dikatakan bahwa pelaksanaan terapi keluarga sangat efektif untuk menolong seseorang dengan masalah yang sangat kompleks dengan rentang yang sangat bervariasi, mulai dari masalah kondisi anak seperti gangguan perasaan, gangguan makan, dan kenakalan remaja, masalah pada orang dewasa dan masalah psikiatri, seperti schizophrenia. (Stratton, 2005).

Fokus dari terapi ini, bukan individual, namun pada keluarga secara keseluruhan. Konsep dasar dari bentuk penatalaksanaannya adalah lebih cepat, lebih 3 logis, lebih menguntungkan, dan lebih ekonomis untuk memperlakukan semua anggota keluarga dalam suatu sistem hubungan dibanding konsentrasi hanya secara individual yang diduga dibutuhkan dalam penatalaksanaan (Goldenberg \& Goldenberg, 1995: Townsend, 2005). Ada beberapa tahap yang dilakukan dalam terapi keluarga yaitu tahap pengkajian awal, tahap intervensi dan tahap terminasi (Shives, 1998), dan tahap pengikatan dan motivasi, tahap perubahan perilaku dan tahap generalisasi (Sexton dan Alexander, dalam Wilson, 2000) yang pelaksanaannya dilakukan secara berurutan, terorganisir dan mempertahankan fokus pada inti permasalahan keluarga dan individu.

Dukungan keluarga adalah bentuk bantuan yang diberikan salah satu anggota keluarga untuk memberi kenyamanan fisik dan psikologis pada saat seseorang mengalami sakit (Friedman, 2014).Keluarga mempunyai peran yang sangat penting bagi kelangsungan hidup penderita diabetes melitus. 3 Menurut penelitian yang dilakukan Skarbec (2006), ditemukan bahwa peran keluarga mempunyai hubungan yang kuat terhadap status kesehatan penderita DM, dimana kurangnya dukungan keluarga akan mempengaruhi kontrol gula darah dan menajemen DM sehingga kualitas hidup akan menurun. Dapat disimpulkan bahwa dukungan keluarga sangat penting dan berpengaruh terhadap kualitas hidup penderita DM. Menurut Hensarling dalam Yusra (2011 ), ada 4 dimensi yang terkandung di dalam dukungan keluarga meliputi dukungan emosional, dukungan 
penghargaan, dukungan instrumental dan dukungan informatif. Penderita DM mempunyai dukungan keluarga yang baik maka penderita akan melakukan sikap positif yaitu dengan melakukan aktivitasaktivitas yang bermanfaat dan akan meningkatkan kualitas hidupnya, sebaliknya penderita DM yang minim atau tidak mempunyai dukungan keluarga maka cenderung melakukan sikap negatif yaitu melakukan kegiatan yang merugikan diri sendiri dan akan menurunkan kualitas hidupnya (Soegondo, 2006).

\section{METODE}

Penelitian ini menggunakan metode intervensi semu (quasi experiment) dengan rancangan pre-post test with control group design untuk mengetahui pengaruh terapi keluarga terhadap dukungan keluarga dalam merawat klien dengan masalah perilaku kekerasan.

Responden penelitian dibagi dalam dua kelompok yaitu kelompok intervensi (perlakuan) dan kelompok kontrol (tanpa perlakukan) kemudian intervensi terapi keluarga diberikan pada kelompok intervensi, sedangkan kelompok kontrol tidak mendapatkan intervensi terapi keluarga. Subyek penelitian ini adalah 2 keluarga yang memenuhi kriteria inklusi.

Teknik sampel yang digunakan adalah consecutive sampling yang terdiri dari 2 keluarga. Variabel terikat yang diukur adalah perbedaan dukungan keluarga dalam merawat klien dengan masalah DM. Pengambilan data dalam penelitian ini dilaksanakan di Dusun Krajan Desa Serut Kecamatan Panti Kabupaten Jember bulan Mei tahun 2018.

HASIL PEMBAHASAN

Gambaran karakteristik responden keluarga yang memiliki anggota keluarga dengan diabetes mellitus tpe 2 pada kelompok intervensi dan kelompok kontrol.
Tabel 1. Distribusi Frekuensi Keluaga Intervensi Berdasarkan usia

\begin{tabular}{lllll}
\hline Variabel & Mean & Median & SD & $\begin{array}{l}\text { Min- } \\
\text { Maks }\end{array}$ \\
\hline $\begin{array}{l}\text { Usia } \\
\text { (Th) }\end{array}$ & 28,44 & 32,0 & 14,14 & $12-48$ \\
\hline
\end{tabular}

Berdasarkan tabel 1, diketahui ratarata usia responden adalah 28,44 tahun dengan standar deviasi 14,14. Gambaran distribusi karakteristik kelompok intervensi berdasarkan jenis kelamin, pendidikan, pekerjaan, dan hubungan dalam anggota keluarga dapat dilihat pada tabel 2 .

Tabel 2. Distribusi Karakteristik Responden Kelompok Intervensi Berdasarkan Jenis Kelamin, Pendidikan, Pekerjaan, Hubungan dalam Keluarga

\begin{tabular}{|c|c|c|c|}
\hline $\begin{array}{l}\text { No } \\
\text {. }\end{array}$ & $\begin{array}{l}\text { Karakteristi } \\
\text { k }\end{array}$ & $\begin{array}{l}\text { Frekuens } \\
\text { i }(\mathbf{F})\end{array}$ & $\begin{array}{l}\text { Presentas } \\
\text { i }(\%)\end{array}$ \\
\hline 1. & $\begin{array}{l}\text { Jenis Kelamin } \\
\text { a. Laki-laki } \\
\text { b. Perempu- } \\
\text { an } \\
\text { Jumlah }\end{array}$ & $\begin{array}{l}5 \\
4 \\
9\end{array}$ & $\begin{array}{l}55,6 \\
44,4 \\
100\end{array}$ \\
\hline 2. & $\begin{array}{l}\text { Pendidikan } \\
\text { a. SD } \\
\text { b. SMP } \\
\text { c. SMA } \\
\text { d. Perguruan } \\
\text { Tinggi } \\
\text { e. Tidak } \\
\text { sekolah } \\
\text { Jumlah }\end{array}$ & $\begin{array}{l}2 \\
4 \\
3 \\
- \\
- \\
9\end{array}$ & $\begin{array}{l}22,2 \\
44,4 \\
33,3 \\
- \\
- \\
100\end{array}$ \\
\hline 3. & $\begin{array}{ll}\text { Pekerjaan } \\
\text { a. } & \text { Tidak } \\
& \text { Bekerja } \\
\text { b. } & \text { Pegawai } \\
\text { negeri } \\
\text { c. Pegawai } \\
\text { Swasta } \\
\text { d. Wiraswast } \\
\text { a } \\
\text { Jumlah }\end{array}$ & $\begin{array}{l}7 \\
- \\
1 \\
1 \\
9\end{array}$ & $\begin{array}{l}77,8 \\
- \\
11,1 \\
11,1 \\
100\end{array}$ \\
\hline
\end{tabular}




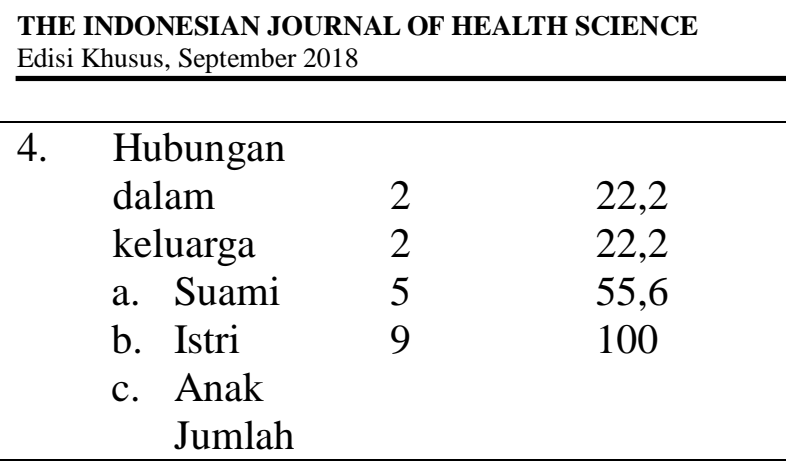

Tabel 2 didapatkan hasil bahwa dari 9 anggota keluarga diketahui jenis kelamin responden sebagian besar jumlah laki-laki sebanyak 5 orang $(55,6 \%)$ dan perempuan sebanyak 4 orang $(44,4 \%)$. Tingkat pendidikan responden yang banyak dari 9 responden 4 orang $(44,4 \%)$ pendidikan terakhirnya adalah SMP. Pekerjaan responden terbanyak yaitu 7 orang $(77,8 \%)$ tidak bekerja dari total 9 responden. Hubungan dalam angota keluarga sebagian besar adalah sebagai anak yakni 5 orang $(55,6 \%)$.

Tabel 3. Distribusi Frekuensi Keluaga kontrol Berdasarkan usia

\begin{tabular}{lllll}
\hline Variabel & Mean & Median & SD & $\begin{array}{l}\text { Min- } \\
\text { Maks }\end{array}$ \\
\hline $\begin{array}{l}\text { Usia } \\
\text { (Th) }\end{array}$ & 32,86 & 40,0 & 18,14 & $12-58$ \\
\hline
\end{tabular}

Berdasarkan tabel 3, diketahui ratarata usia responden kelompok kontrol adalah 32,86 tahun dengan standar deviasi 18,14. Gambaran distribusi karakteristik kelompok kontrol berdasarkan jenis kelamin, pendidikan, pekerjaan, dan hubungan dalam anggota keluarga dapat dilihat pada tabel 4 .

Tabel 4. Distribusi Karakteristik Responden Kelompok Intervensi Berdasarkan Jenis Kelamin, Pendidikan, Pekerjaan, Hubungan dalam Keluarga

\begin{tabular}{llll}
\hline $\begin{array}{l}\text { No } \\
.\end{array}$ & $\begin{array}{l}\text { Karakteristi } \\
\mathbf{k}\end{array}$ & $\begin{array}{l}\text { Frekuens } \\
\mathbf{i}(\mathbf{F})\end{array}$ & $\begin{array}{l}\text { Presentas } \\
\mathbf{i}(\boldsymbol{\%})\end{array}$ \\
\hline 1. & Jenis Kelamin & & \\
\hline
\end{tabular}

\begin{tabular}{|c|c|c|c|}
\hline & $\begin{array}{l}\text { c. Laki-laki } \\
\text { d. Perempu- } \\
\text { an } \\
\text { Jumlah }\end{array}$ & $\begin{array}{l}5 \\
2 \\
7\end{array}$ & $\begin{array}{l}71,4 \\
28,6 \\
100\end{array}$ \\
\hline 2. & \begin{tabular}{ll}
\multicolumn{2}{l}{ Pendidikan } \\
f. & SD \\
g. & SMP \\
h. & SMA \\
i. & Perguruan \\
& Tinggi \\
j. & Tidak \\
& sekolah \\
Jumlah
\end{tabular} & $\begin{array}{l}3 \\
2 \\
2 \\
- \\
- \\
7\end{array}$ & $\begin{array}{l}42,9 \\
28,6 \\
28,6 \\
- \\
- \\
100\end{array}$ \\
\hline 3. & \begin{tabular}{ll}
\multicolumn{2}{l}{ Pekerjaan } \\
e. Tidak \\
Bekerja \\
f. Pegawai \\
negeri \\
g. Pegawai \\
Swasta \\
h. Wiraswast \\
a \\
Jumlah
\end{tabular} & $\begin{array}{l}5 \\
- \\
1 \\
1 \\
7\end{array}$ & $\begin{array}{l}71,4 \\
- \\
14,3 \\
14,3 \\
100\end{array}$ \\
\hline 4. & $\begin{array}{ll}\text { Hubungan } \\
\text { dalam } \\
\text { keluarga } \\
\text { d. Suami } \\
\text { e. Istri } \\
\text { f. Anak } \\
& \text { Jumlah }\end{array}$ & $\begin{array}{l}2 \\
2 \\
3 \\
7\end{array}$ & $\begin{array}{l}28,6 \\
28,6 \\
42,9 \\
100\end{array}$ \\
\hline
\end{tabular}

Tabel 4 didapatkan hasil bahwa dari 7 anggota keluarga diketahui jenis kelamin responden sebagian besar jumlah laki-laki sebanyak 5 orang $(71,4 \%)$ dan perempuan sebanyak 2 orang $(28,6 \%)$. Tingkat pendidikan responden yang banyak dari 9 responden 3 orang $(42,9 \%)$ pendidikan terakhirnya adalah SD. Pekerjaan responden terbanyak yaitu 5 orang $(71,4 \%)$ tidak bekerja dari total 7 responden. Hubungan dalam angota keluarga sebagian besar adalah sebagai anak yakni 3 orang (42,9\%).

\section{Dukungan Keluarga dalam Merawat Anggota Keluarga yang memiliki DM}




\section{Tipe 2 Kelompok Perlakuan}

Tabel 5. Perbedaan Nilai Dukungan Keluarga Sebelum dan Setelah Pemberian Terapi Edukasi

\begin{tabular}{|c|c|c|c|c|}
\hline Variabel & Me & Median & I SD & $\begin{array}{l}\text { Min- } p \\
\text { Maks value }\end{array}$ \\
\hline $\begin{array}{c}\text { Dukungan } \\
\text { Pretest }\end{array}$ & 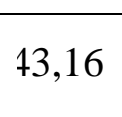 & 40,00 & 7,493 & $38-55$ \\
\hline $\begin{array}{c}\text { Dukungan } \\
\text { Posttest }\end{array}$ & 56,29 & 56,00 & 2,059 & $54-60$ \\
\hline
\end{tabular}

Tabel 4 menunjukkan terjadi peningkatan rata-rata nilai dukungan keluarga sebesar 13,13 yaitu dari 43,16 sebelum diberikan terapi edukasi menjadi 56,29 setelah diberikan terapi edukasi. $p=0,001<\alpha \quad(\alpha=0,05)$ maka dapat disimpulkan bahwa ada perbedaan signifikan antara nilai rata-rata dukungan keluarga sebelum dan setelah diberikan terapi edukasi pada responden kelompok perlakuan.

Tabel 6. Perbedaan Kategori Dukungan Keluarga Sebelum dan Setelah penkes dan latihan

\begin{tabular}{ccccc}
\hline Kategori & Pretest & $\mathbf{( \% )}$ & Posttest & $(\%)$ \\
\hline Baik & 2 & $28,6 \%$ & 7 & $100 \%$ \\
Kurang & 5 & $71,4 \%$ & - & $0 \%$ \\
\hline Total & 7 & $100 \%$ & 7 & $100 \%$ \\
\hline
\end{tabular}

Tabel 6 menunjukkan jumlah responden dengan dukungan keluarga kategori baik bertambah dari 2 responden $(28,6 \%)$ menjadi 7 responden $(100 \%)$ pada kelompok perlakuan.

\section{Dukungan Keluarga Kelompok Kontrol}

Tabel 7. Perbedaan Nilai Dukungan Keluarga pretest dan posttest

\begin{tabular}{|c|c|c|c|c|}
\hline $\operatorname{aria}$ & & $\begin{array}{c}\text { Media } \\
\text { n }\end{array}$ & & $\begin{array}{cc}\text { Min- } & p \\
\text { Mak } & \text { valt }\end{array}$ \\
\hline
\end{tabular}

\begin{tabular}{cccccc}
\hline & & & & $\mathbf{s}$ & $\boldsymbol{e}$ \\
\hline Pretest & 42,2 & 45,00 & 5,76 & $36-48$ & \\
& 0 & 2 & & 1,698 \\
Posttest & 35,8 & 36,00 & 1,30 & $34-37$ & \\
& 0 & 4 & 34 & \\
\hline
\end{tabular}

Tabel 6 menunjukkan bahwa terjadi penurunan rata-rata nilai dukungan keluarga sebesar 6,4 yaitu dari 42,20 saat pretest menjadi 35,80 pada saat posttest kelompok kontrol dengan standar deviasi 5,762 pada pretest dan 1,304 pada posttest.

Tabel 7. Perbedaan Kategori Dukungan Keluarga pretest dan posttest pada kelompok control

\begin{tabular}{ccccc}
\hline Kategori & Pretest & $(\%)$ & Posttest & $(\%)$ \\
\hline Baik & - & $0 \%$ & - & $0 \%$ \\
Kurang & 5 & $100 \%$ & 5 & $100 \%$ \\
\hline Total & 5 & $100 \%$ & 5 & $100 \%$ \\
\hline
\end{tabular}

Tabel 7 menunjukkan jumlah responden dengan dukungan keluarga kurang pada kedua pretest dan posttest pada kelompok kontrol yaitu sebanyak 5 orang (100\%).

\section{Dukungan Keluarga Setelah terapi edukasi pada Kelompok Perlakuan dan Kelompok Kontrol}

Tabel 8. Perbedaan Perilaku Lansia Kelompok Perlakuan dan Kelompok Kontrol Setelah terapi edukasi

\begin{tabular}{cccc}
\hline Variabel & $\begin{array}{c}\text { Mean } \\
\text { Difference }\end{array}$ & $\mathbf{t}$ & $\begin{array}{c}\boldsymbol{p} \\
\text { value }\end{array}$ \\
\hline $\begin{array}{c}\text { Difference } \\
\text { Posttest-Pretest } \\
\text { antara ke- }\end{array}$ & & & \\
$\begin{array}{c}\text { lompok perla- } \\
\text { kuan dan } \\
\text { kontrol }\end{array}$ & 20,456 & 19,488 & 0,001 \\
\hline
\end{tabular}

Tabel 8 menunjukkan hasil uji $t$ independent terhadap variabel beda nilai 
dukungan keluarga pada kelompok perlakuan dan kelompok kontrol yaitu $\mathrm{p}=0,001 \quad(\mathrm{p}<0,05)$ bahwa terdapat perbedaan signifikan nilai dukungan keluarga antara kelompok perlakuan dan kelompok kontrol. Nilai positif pada $t$ menunjukkan bahwa nilai dukungan keluarga lebih tinggi pada kelompok perlakuan dibandingkan pada kelompok kontol. Kesimpulan dari pernyataan tersebut adalah Ha diterima dan membuktikan terdapat pengaruh yang signifikan antara terapi edukasi terhadap dukungan keluarga dalam merawat anggota keluarga dengan diabetes melllitus tipe 2 di Desa Serut Kecamatan Panti Kabupaten Jember.

\section{PEMBAHASAN}

\section{Karakteristik Responden}

Setelah dilakukan uji statistik $\mathrm{T}$ dependen dan independen yang didasarkan pada taraf signifikan atau taraf kemaknaan adalah $\alpha<0,05$ dan didapatkan $\mathrm{p}=0,001$ maka Ha diterima dan Ho ditolak berarti terbukti bahwa terapi edukasi keluarga dapat meningkatkan dukungan keluarga dalam merawat anggota keluarganya yang menderita DM tipe 2 di desa Serut, Kecamatan Panti, Jember. Bentuk dukungan keluarga yang diberikan kepada pasien adalah berupa 1) Dukungan informasional yaitu keluarga berfungsi sebagai sebuah kolektor dan diseminator (penyebar) informasi tentang dunia. Menjelaskan tentang pemberian saran, sugesti, informasi yang dapat digunakan mengungkapkan suatu masalah. Manfaat dari dukungan ini adalah dapat menekan munculnya suatu stressor karena informasi yang diberikan dapat menyumbangkan aksi sugesti yang khusus pada individu. Aspek-aspek dalam dukungan ini adalah nasehat, usulan, saran, petunjuk dan pemberian informasi. 2) Dukungan penilaian atau penghargaan yaitu keluarga bertindak sebagai sebuah bimbingan umpan balik, membimbing dan menengahi pemecahan masalah, sebagai sumber dan validator indentitas anggota keluarga diantaranya memberikan support, penghargaan, perhatian. 3) Dukungan instrumental yaitu keluarga merupakan sebuah sumber pertolongan praktis dan konkrit, diantaranya: kesehatan penderita dalam hal kebutuhan makan dan minum, istirahat, terhindarnya penderita dari kelelahan, serta 4) Dukungan emosional yaitu keluarga sebagai tempat yang aman dan damai untuk istirahat dan pemulihan serta membantu penguasaan terhadap emosi. Aspek-aspek dari dukungan emosional meliputi dukungan yang diwujudkan dalam bentuk afeksi, adanya kepercayaan, perhatian, mendengarkan dan didengarkan.

Efektivitas dukungan keluarga dipengaruhi oleh beberapa hal diantaranya adalah Faktor Internal dan Faktor Eksternal. Faktor internal meliputi : 1) Tahap perkembangan yang artinya dukungan dapat ditentukan oleh faktor usia dalam hal ini adalah pertumbuhan dan perkembangan, dengan demikian setiap rentang usia (bayilansia) memiliki pemahaman dan respon terhadap perubahan kesehatan yang berbeda - beda. 2) Pendidikan atau Tingkat Pengetahuan dikarenakan keyakinan seseorang terhadap adanya bentuk dukungan terbentuk oleh variabel intelektual yang terdiri dari pengetahuan, dan pengalaman masa lalu. Kemampuan kognitif akan membentuk cara berfikir seseorang termasuk kemampuan memahami faktor-faktor yang berhubungan dengan penyakit dan menggunakan pengetahuan tentang kesehatan untuk menjaga kesehatan dirinya. 3) Faktor Emosi. Faktor emosional juga mempengaruhi keyakinan terhadap adanya dukungan dan cara melaksanakannya. Seseorang yang mengalami respon stress dalam setiap perubahan hidupnya cenderung berespon terhadap berbagai tanda sakit, mungkin dilakukan dengan cara mengkhawatirkan bahwa penyakit tersebut 
dapat mengancam kehidupannya. Seseorang yang secara umum terlihat sangat tenang mungkin mempunyai respon emosional yang kecil selama ia sakit. Seorang individu yang tidak mampu melakukan koping secara emosional terhadap ancaman penyakit mungkin akan menyangkal adanya gejala penyakit pada dirinya dan tidak mau menjalani pengobatan. 4) Faktor Spiritual. Aspek spiritual dapat terlihat bagaimana seseorang menjalani kehidupannya, mencakup nilai dan keyakinan yang dilaksanakan, hubungan dengan keluarga atau teman, dan kemampuan mencari harapan dan arti dalam hidup.

Sedangkan Faktor eksternal meliputi :

1) Praktik di Keluarga berupa cara bagaimana keluarga memberikan dukungan biasanya mempengaruhi penderita dalam melaksanakan kesehatannya. 2) Faktor sosial dan psikososial, yaitu faktor sosial dan psikososial dapat meningkatkan resiko terjadinya penyakit dan dapat mempengaruhi cara seseorang mendefinisikan dan bereaksi terhadap penyakitnya. Variabel psikososial mencakup : stabilitas perkawinan, gaya hidup, dan lingkungan kerja. Seseorang biasanya akan mencari dukungan dan persetujuan dari kelompok sosialnya, hal ini akan mempengaruhi keyakinan kesehatan dan cara pelaksanaannya. Semakin tinggi tingkat ekonomi seseorang biasanya ia akan cepat tanggap terhadap gejala penyakit yang dirasakan. Sehingga ia akan segera mencari pertolongan ketika merasa ada gangguan pada kesehatannya. 3) Latar belakang budaya. Latar belakang budaya mempengaruhi keyakinan, nilai, dan kebiasaan individu, dalam memberikan dukungan termasuk cara pelaksanaan kesehatan pribadi.

Hasil penelitian menunjukkan ada bukti bahwa terapi edukasi keluarga dapat meningkatkan dukungan keluarga dalam merawat klien dengan Diabetes Mellitus.
Hal ini disebabkan karena adanya pemberian terapi edukasi baik itu berupa diit dan peningkatan pemeliharaan kesehatan secara kontinyu dapat merubah pandangan keluarga dalam merawat anggota keluarganya yang menderita diabetes mellitus. Dukungan keluarga yang baik pada klien DM dalam menjalani terapi diet dan pengobatan membuat pasien Diabetes Mellitus menjadi termotivasi untuk menjalani pola makan seimbang. Dalam penelitian ini, pasien Diabetes Melitus merasakan bahwa keluarganya telah mampu mewujudkan dukungan keluarga baik secara dukungan informasional, dukungan emosional, dukungan instrumental, dan dukungan penilaian. Penatalaksanaan Diabetes Mellitus adalah perencanaan makan (diet), latihan fisik, dan pengobatan. Dalam menjalani terapi diet, dukungan dalam keluarga sangatlah diperlukan agar pasien Diabetes Mellitus merasa nyaman dan tentraman untuk menjalani diet Diabetes Mellitus. Selain itu pasien Diabetes Mellitus patuh dalam melaksanakan perintah, mentaati aturan dan disiplin dalam menjalankan program pengobatan yang sudah ditentukan, sehingga komplikasi dapat dikendalikan.

\section{SIMPULAN}

Simpulan dari penelitian yaitu: 1) karakteristik responden pada kelompok kontrol dan intervensi menunjukkan rerata usia adalah 28 tahun dan 32 tahun; 2) Terapi edukasi berupa Pendkes tentang DM dapat meningkatkan dukungan keluarga dalam mengendalikan hipertensi. Hal ini dikarenakan pemberian edukasi dan program latihan rutin mampu memotivasi lansia untuk lebih memperhatikan perawatan kesehatan serta dan memiliki kesadaran untuk berperilaku sesuai dengan pola hidup sehat.

\section{SARAN}


Berdasarkan hasil penelitian ini diharapkan keluarga lebih termotivasi untuk memberikan dukungan yang diberikan kepada pasien Diabetes Mellitus dalam meningkatkan kepatuhan diet pada pasien Diabetes Mellitus.

Perawat diharapkan lebih termotivasi untuk meningkatkan pengetahuan keluarga yang memiliki anggota keluarga yang menderita penyakit Diabetes Mellitus dengan cara memberikan terapi edukasi berupa pendidikan kesehatan maupun demo atau praktek perawatan klien diabetes mellitus. Terapi edukasi yang telah diberikan diharapkan dapat meningkatkan dukungan keluarga sehingga klien dengan DM dapat menjalankan kepatuhan terapi pengobatannya.

\section{UCAPAN TERIMA KASIH}

Penulis menyampaikan terima kasih kepada seluruh responden, dosen pembimbing, dan pihak Desa Serut Kecamatan Panti, Kabupaten Jember.

\section{KEPUSTAKAAN}

Bryant, L.L; Altpeter, M; Whitelaw, N.A. 2006. Evaluation of Health Promotion Programs for older adults: an introduction.

Dashtbozorgi B, Chadirian F, Khajeddin N, Karami K. 2009. Effect of family psychoeducation on the level of adaptation and improvement of patients with mood disorders. Iran J Psychiat Clinical Psychol.

Paddison C. 2010. Familly support and conflict among aduls with type 2 diabetes. Europ Diabet Nurs.

Sugiono 2014, Statistika Untuk Penelitian, Alfabeta, Bandung.

Tanriverdi D, Ekinci M. 2012. The Effect psychoeducation intervention has on the caregiving burden of caregivers for schizophrenic patients in Turkey. Int J Nurs Pract.

Williamson JD, Suplano MA, Aplegate WB, et al. 2016. Intensive vs standard blood pressure control and cardiovascular disease outcomes in adults aged $\geq 75$ years: a randomized clinical trial. JAMA.

Weiss J, Freeman M, Low A, et al. 2017. Benefits and harms of intensive blood pressure treatment in adults aged 60 years or older; a systematic review and meta-analysis. Ann Intern Med. 